Sol ubi I i zati on of the ecdysone bi ndi ng prot ei $n$ from anterior silk gl and cel I mentoranes of the sil kworm bonbyx mori

\begin{tabular}{|l|l|}
\hline 著者 & El nogy Nohaned, I wam Nasaf um, Sakur ai Sho \\
\hline $\begin{array}{l}\text { j our nal or } \\
\text { publ i cat i on t i t I e }\end{array}$ & Zool ogi cal sci ence \\
\hline vol une & 24 \\
\hline number & 10 \\
\hline page r ange & $971-977$ \\
\hline year & $2007-10-01$ \\
\hline URL & ht t p: //hdl . handl e. net /2297/28990 \\
\hline
\end{tabular}




\title{
Solubilization of the Ecdysone Binding Protein from Anterior Silk Gland Cell Membranes of the Silkworm, Bombyx mori
}

\author{
Mohamed Elmogy ${ }^{\dagger}$, Masafumi Iwami and Sho Sakurai ${ }^{\star}$ \\ Division of Life Sciences, Graduate School of Science and Technology, \\ Kanazawa University, Kakumamachi 920-1192, Japan
}

\begin{abstract}
We previously provided preliminary evidence for the presence of a putative membrane ecdysone receptor (mEcR) anchored in the plasma membranes of anterior silk glands (ASGs) in Bombyx mori. This receptor may act in concert with the conventional EcR in 20E-dependent programmed cell death of these glands. We report here, for the first time, the solubilization of $\mathrm{mEcR}$ from ASG membranes using the zwitterionic detergent $\mathrm{CHAPS}$ in the presence of $\mathrm{NaCl}$. Our results show by ligand binding assay that $\mathrm{mEcR}$ solubilized this way is functionally active and retains $75 \%$ of its native binding activity. We also defined experimental conditions that yielded protein/detergent complexes with partial binding activity, which makes it possible to purify the membrane-bound ecdysone binding protein.
\end{abstract}

Key words: anterior silk gland, ecdysteorid, membrane ecdysone receptor, detergent, solubilization, Bombyx mori

\section{INTRODUCTION}

Recognition of the complexity of steroid signaling has substantially increased in recent years. Steroids enter cells and bind to ligand-regulated transcription factors (Beato and Klug, 2000; Henrich, 1999). However, steroids also exert non-genomic effects that occur independently of gene transcription (Falkenstein et al., 2000). Recent studies suggest that steroid hormones bind receptors on cellular membranes to gain access to the intracellular compartment and modulate cellular functions (Watson and Gametchu, 1999). Typically, these effects are initiated at the plasma membrane and result in the regulation of membrane protein-mediated intracellular signaling pathways (Sarramegna et al., 2006). The dependence of the native conformation of these proteins in the hydrophobic intra-membrane environment has complicated attempts to isolate those integral surface receptor molecules (Neugebauer, 1990).

The anterior silk glands (ASGs) of the silkworm, Bombyx mori, begin to undergo programmed cell death (PCD) in response to a high hemolymph concentration of ecdysteroid, which induces pupal metamorphosis (Terashima et al., 2000). The biologically active form of ecdysone, 20hydroxyecdysone (20E), binds to a functional nuclear ecdysone receptor consisting of an ecdysone receptor $(E c R)$ and its heterodimeric partner, Ultraspiracle (USP), and thereby controls the transcriptional activity of target genes (Riddiford

\footnotetext{
* Corresponding author. Phone: +81-76-264-6250;

Fax : +81-76-264-6255;

E-mail : ssakurai@kenroku.kanazawa-u.ac.jp

† Present address: Department of Entomology, Faculty of Science, Cairo University, Giza, Egypt

doi:10.2108/zsj.24.971
}

et al., 2000). We previously provided preliminary evidence for the presence of a putative membrane ecdysone receptor (mEcR) located in the plasma membranes of B. mori ASGs, which may act in concert with the conventional nuclear EcR (Elmogy et al., 2004, 2006). Thus, to further characterize $\mathrm{mEcR}$, we tried to solubilize from ASGs a functional mEcR retaining its binding activity to ecdysteroids. Since no single detergent or solubilization scheme is universally applicable to all membrane proteins (Tanford and Reynolds, 1976; Kerkhoff et al., 1996, 2000), the important aspect of the present approach is the use of an apporopriate detergent as a solubilizing agent.

Detergent solubilization is a crucial step for the purification and characterization of membrane-bound receptors. This is effectively accomplished by amphiphilic detergents in a process known as solubilization (Banerjee, 1999; Hjelmeland and Chrambach, 1984; Jones et al., 1987). Solubilization of a membrane protein that retains its biological activity is a formidable challenge, since many detergents irreversibly denature membrane proteins (Garavito and Ferguson-Miller, 2001).

The mild, nondenaturing zwitterionic detergent 3-[(3cholamidopropyl)-dimethylammonio]-1-propanesulfonate (CHAPS) is one of the most commonly used detergents in membrane biochemistry (Hjelmeland, 1980). CHAPS is a derivative of naturally occurring bile salts and has useful features of both the bile salt hydrophobic group and the $\mathrm{N}$ alkyl sulfobetaine-type polar group (Hjelmeland, 1980; Hjelmeland and Chrambach, 1984). Also, CHAPS has very low absorbance at $280 \mathrm{~nm}$ (unlike TritonX-100) and does not have circular dichroic activity in the far UV region, making it ideal for optic studies of proteins. These factors have led to extensive use of this detergent in solubilization of 
membrane receptors (Banerjee et al., 1995; Ofri et al., 1992).

Here, we report the solubilization of $\mathrm{mEcR}$ from $B$. mori ASGs using CHAPS in the presence of $\mathrm{NaCl}$, followed by dissociation of protein/lipid/CHAPS mixed micelles into pro-
tein/CHAPS complexes, which appeared in high enough quantity to be adopted for protein purification. We also show by ligand-binding assay that $\mathrm{mEcR}$ solubilized by this way is functionally active.
(A)
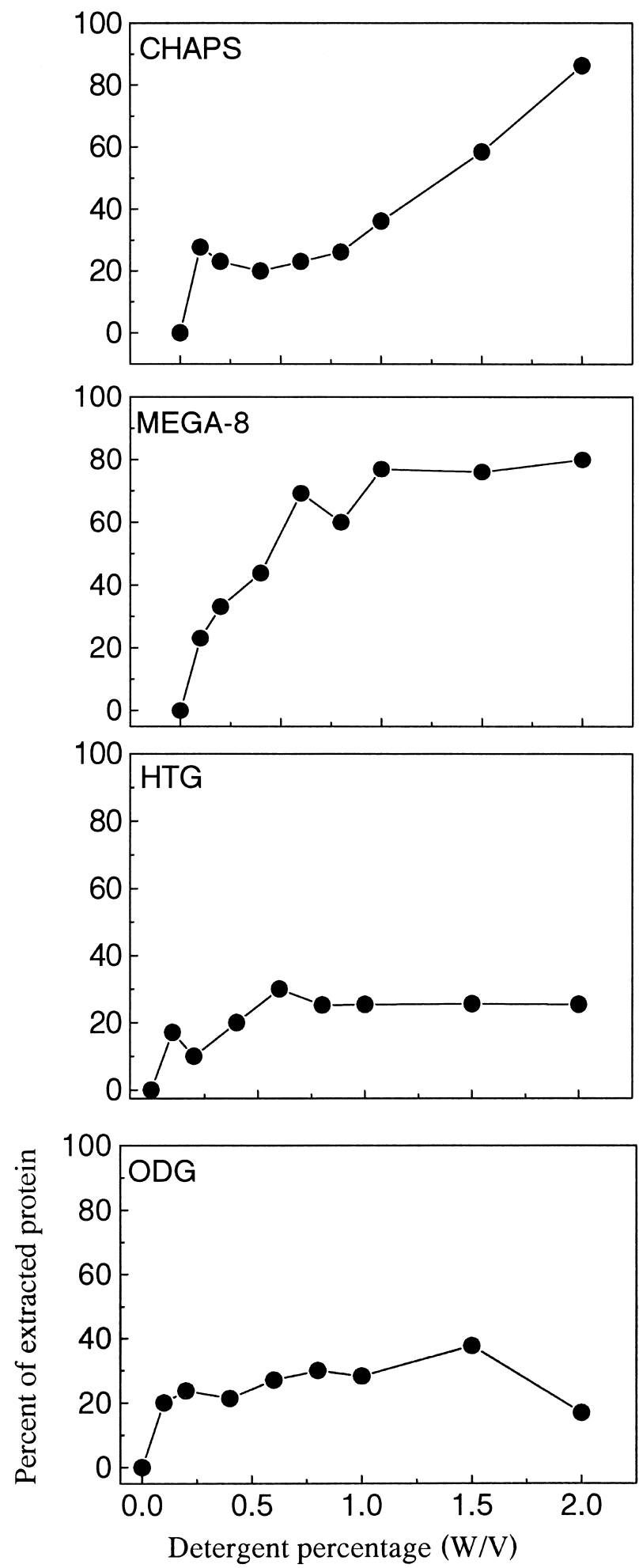
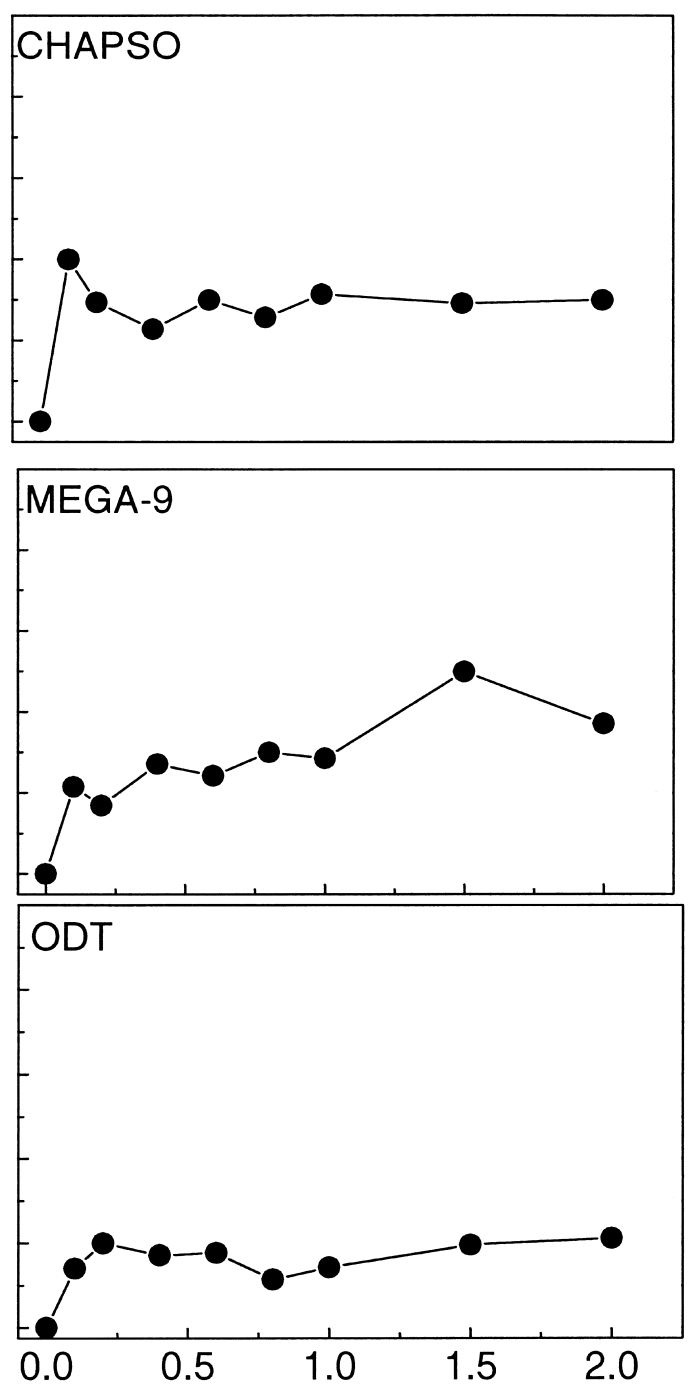

Detergent percentage (W/V)

Continued. 
(B)

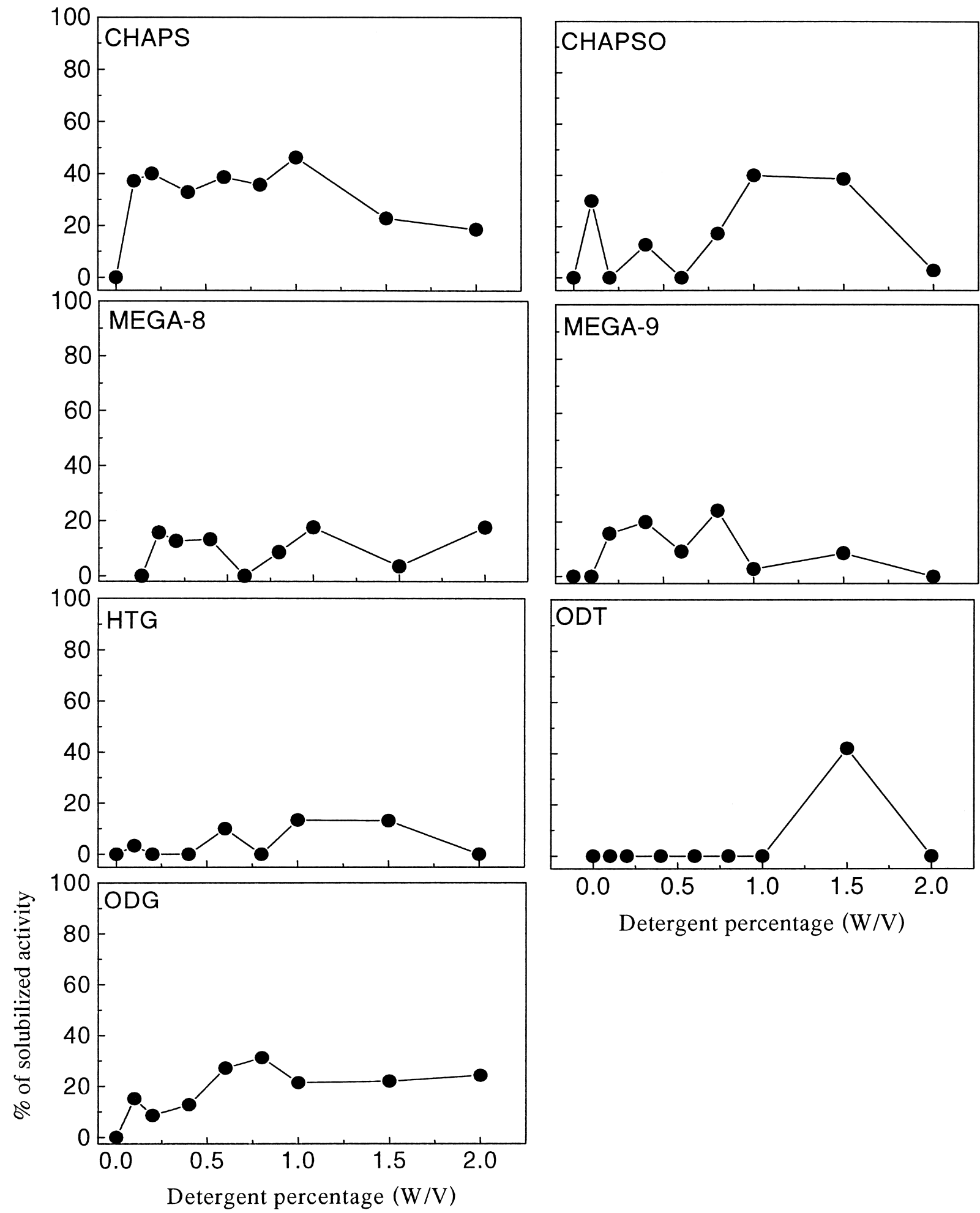

Fig. 1. Initial solubilization using zwitterionic and nonionic detergents. Membrane fractions from ASGs, prepared as described in Materials and Methods, were suspended in assay buffer to a final protein concentration of $1 \mathrm{mg} / \mathrm{ml}$ and treated with varied concentrations of the detergents CHAPS, CHAPSO, MEGA-8, MEGA-9, HTG, OTG, and OG. (A) Extracted proteins in supernatants (ordinate) are shown as a percentage of those in the crude membrane preparations. (B) Solubilized activity (ordinate) is shown as the percentage of binding activity in the supernatant relative to that in the crude membrane preparation. Each datum point is the mean of duplicate determinations. 


\section{MATERIALS AND METHODS}

\section{Animals and ASGs}

Larvae of $B$. mori (Kinshu $x$ Showa, an F1 hybrid stock of Chinese and Japanese strains) were reared on an artificial diet (Silkmate, Nihon-Nosan-Kogyo, Yokohama, Japan) at $25^{\circ} \mathrm{C}$ under a 12-h light/12-h dark cycle (Sakurai, 1994). ASGs were dissected on the day of gut purge (Terashima et al., 2000) and cultured separately in $0.3 \mathrm{ml}$ Grace's insect culture medium (Gibco BRL, Rockville, MD) at $25^{\circ} \mathrm{C}$ for $18 \mathrm{~h}$ with $1 \mu \mathrm{M} 20 \mathrm{E}$, followed by culture in a hormone-free medium for further $12 \mathrm{~h}$. Because the binding activity in membrane fractions prepared from cultured ASGs is higher than that in freshly dissected ASGs (Elmogy et al., 2004), we mainly used cultured ASGs.

\section{Hormones and reagents}

The reagents 3-[(3-Cholamidopropyl)-dimethylammonio]-1-propanesulfonate (CHAPS), 3-[(3-cholamidopropyl) dimethylammonio]2-hydroxypropanesulfonic acid (CHAPSO), n-heptyl- $\beta$-D-thioglucoside (HTG), n-octanoyl- $N$-methylglucamide (MEGA-8), nonanoyl- $N$ methylglucamide (MEGA-9), n-octyl- $\beta$-D-glucoside, and n-octyl- $\beta$-Dthioglucoside were purchased from Wako Pure Chemical Industries (Osaka, Japan). Ponasterone A (PonA, 25-deoxy-20-hydroxyecdysone) and $20 \mathrm{E}$ were obtained from Sigma (St.Louis, MO). Ecdysteroids were dissolved in ethanol and stored at $-20^{\circ} \mathrm{C}$ until use. $\left[{ }^{3} \mathrm{H}\right]$ PonA (200 Ci/mmol) was obtained from Perkin-Elmer Life Science (Boston, MA).

\section{Preparation of crude membrane fraction}

Cultured ASGs were washed three times with insect Ringer's solution ( $130 \mathrm{mM} \mathrm{NaCl}, 4.7 \mathrm{mM} \mathrm{KCl}, 1.9 \mathrm{mM} \mathrm{CaCl}$ ). All subsequent procedures were performed at $4^{\circ} \mathrm{C}$. ASGs were homogenized in seven volumes of assay buffer $(20 \mathrm{mM}$ Tris/ $\mathrm{HCl}, \mathrm{pH} 7.0,2 \mathrm{mM}$ EDTA, $1 \mathrm{mM}$ phenylmethylsulphonyl fluoride, $3 \mu \mathrm{g} / \mathrm{ml}$ pepstatin $\mathrm{A}$, $3 \mu \mathrm{g} / \mathrm{ml}$ leupeptin) using a motor-driven, loose-fitting glass-plastic homogenizer at $1,000 \mathrm{rpm}$ for $1 \mathrm{~min}$. After centrifugation at $1,000 \times \mathrm{g}$ for $10 \mathrm{~min}$, the resulting pellet was suspended in the buffer and centrifuged at $1,500 \times \mathrm{g}$ for $10 \mathrm{~min}$. The pellet was suspended again in buffer and centrifuged at $1,800 \times \mathrm{g}$ for $10 \mathrm{~min}$. The resulting pellet was resuspended in buffer, homogenized again using an HG30 homogenizer (Hitachi) on ice, and centrifuged at $1,000 \times \mathrm{g}$ for 10 $\mathrm{min}$. The supernatant was centrifuged at $8,000 \times \mathrm{g}$ for $10 \mathrm{~min}$, and the resulting supernatant was centrifuged at $105,000 \times \mathrm{g}$ for $5 \mathrm{~h}$. The pellet was suspended in buffer, frozen with liquid nitrogen, and stored at $-80^{\circ} \mathrm{C}$ until use. Crude membrane fractions of ASGs (1 $\mathrm{mg} / \mathrm{ml}$ ) were treated with different concentrations of individual detergents for $60 \mathrm{~min}$ at $4^{\circ} \mathrm{C}$ with constant stirring, then centrifuged at $105,000 \times \mathrm{g}$ for $60 \mathrm{~min}$ at $4^{\circ} \mathrm{C}$. The binding activity of the supernatant, measured immediately after centrifugation, was regarded as 'solubilized activity', and the protein amounts in the supernatant were regarded as extracted proteins. Protein amounts were measured using a DC Protein Assay Kit (Bio-Rad, Hercules, CA) with $\mathrm{BSA}$ as a standard.

\section{Preparation of P1 and P2 membranes from crude membranes of ASGs}

Crude membrane suspensions containing $5 \mathrm{mg} / \mathrm{ml}$ proteins were treated with solutions of high ionic strength (binding assay buffer containing $1 \mathrm{M} \mathrm{NaCl}$ ) for $60 \mathrm{~min}$ at $4^{\circ} \mathrm{C}$. After centrifugation at $105,000 \times \mathrm{g}$ for $1 \mathrm{~h}$, the resulting pellet (P1) was resuspended in the binding assay buffer to a final protein concentration of $20 \mathrm{mg} / \mathrm{ml}$ and stored in aliquots at $-80^{\circ} \mathrm{C}$. P1 membrane suspensions containing $5 \mathrm{mg} / \mathrm{ml}$ protein were each treated with $0.05 \% \mathrm{MEGA}-8$ at $4^{\circ} \mathrm{C}$ for 60 min with constant stirring and again centrifuged at $105,000 \times \mathrm{g}$ for $60 \mathrm{~min}$ at $4^{\circ} \mathrm{C}$. The resulting pellet (P2) was resuspended into binding assay buffer to a final protein concentration of $20 \mathrm{mg} / \mathrm{ml}$ and stored in aliquots at $-80^{\circ} \mathrm{C}$.

\section{Solubilization of the membrane proteins}

$\mathrm{P} 1$ and P2 membranes were resuspended in the binding assay buffer to a final protein concentration of $1 \mathrm{mg} / \mathrm{ml}$ and treated with combinations of increasing concentrations of CHAPS and $\mathrm{NaCl}$. The mixtures were then incubated at $4^{\circ} \mathrm{C}$ for $60 \mathrm{~min}$ with constant stirring and centrifuged at $105,000 \times \mathrm{g}$ for $60 \mathrm{~min}$ at $4^{\circ} \mathrm{C}$. The binding activity in the supernatant, measured immediately after centrifugation, was regarded as 'solubilized activity'.

\section{Binding assay}

Specific binding of $\left[{ }^{3} \mathrm{H}\right]$ PonA was assayed in the solubilization experiments by the use of modified dextran-coated active charcoal (DCC) (Yoshikuni et al., 1993). The dialysed supernatants of the solubilized membrane fractions were incubated for $10 \mathrm{~min}$ at $25^{\circ} \mathrm{C}$ with $25 \mathrm{nM}\left[{ }^{3} \mathrm{H}\right]$ PonA without or with a 1,000-fold molar excess of inert PonA. DCC buffer $(200 \mu \mathrm{l}$; charcol-dextran in $20 \mathrm{mM}$ Tris $/ \mathrm{HCl}$ $\mathrm{pH}$ 7.0, $2 \mathrm{mM}$ EDTA, $1 \mathrm{mM}$ phenylmethylsulphonyl fluoride, $3 \mu \mathrm{g} / \mathrm{ml}$ pepstatin A, $3 \mu \mathrm{g} / \mathrm{ml}$ leupeptin) was added, mixed, and incubated for $10 \mathrm{~min}$ at $4^{\circ} \mathrm{C}$. After incubation, the mixture was centrifuged at $6,000 \times \mathrm{g}$ for $10 \mathrm{~min}$ at $4^{\circ} \mathrm{C}$. The radioactivity in the supernatants was then measured using a Beckman LS-700 counter with a dual-label program (Beckman-Coulter). The potency of DCC buffer for separating free $\left[{ }^{3} \mathrm{H}\right]$ PonA was examined using different concentrations of DCC buffer at five combinations of charcoal / dextran concentrations $(0.25 \% / 0.0025 \%, 0.5 \% / 0.0025,1 \% / 0.025 \%, 0.5 \% / 0.05 \%$, and $1 \% / 0.1 \%)$. The most potent concentration ratio of the DCC buffer was $1 \%$ charcoal: $0.025 \%$ dextran (data not shown), and this ratio was used for measurements of specific binding of $\left[{ }^{3} \mathrm{H}\right] \mathrm{PonA}$.

\section{RESULTS AND DISCUSSION}

The purification of a membrane-bound protein requires the solubilization of proteins. Effective solubilization requires both the selection of a good detergent and the determination of appropriate solubilization conditions. We first examined seven detergents to extract proteins from membranes of freshly dissected ASGs (Fig. 1).

Among the detergents tested, CHAPS and MEGA-8 were the most effective for extracting membrane proteins from ASG membranes. Approximately $80 \%$ of proteins in the membrane suspension were extracted with $2 \%$ of CHAPS and $1 \%$ MEGA-8. Other detergents were not capable of effectively solubilizing proteins, as the maximum amount of extracted protein was less than $40 \%$ of proteins in the membrane suspension before the extraction (Fig. 1A). [ $\left.{ }^{3} \mathrm{H}\right]$ PonA binding activities of the solubilized crude membrane fractions are shown as a function of increasing concentrations of various detergents in Fig. 1B. The specific activity solubilized was estimated by measuring the binding activity in the supernatants immediately after centrifugation of the mixture of membrane fractions with each detergent. The maximal solubilized binding activity was observed with $1 \%$ CHAPS and accounted for $46.2 \%$ of the binding activity in the crude membrane fractions (Table 1). However, the protein concentration in the supernatant with $1 \%$ of CHAPS was $36.2 \%$ of that in the crude membrane fractions. The maximal protein concentration solubilized in the supernatants was observed with $1 \%$ MEGA-8 and accounted for $76.9 \%$ of that in the crude membrane fractions. However, the solubilized binding activity at $1 \%$ of MEGA-8 was only $17.5 \%$ of the binding activity in the crude membrane fractions. This result indicates that a very low concentration, $0.05 \%$, of MEGA-8 was useful for the initial dispersal of lipid and fragmentation of the membranes. Of the seven detergents, CHAPS, 
Table 1. Concentrations of zwitterionic and nonionic detergents that show maximum percentage of solubilization.

\begin{tabular}{lccc}
\hline Detergent & $\begin{array}{c}\text { Detergent }(w / v) \text { for } \\
\text { max. solubilization }\end{array}$ & $\begin{array}{c}\% \text { of solubilized } \\
\text { binding activity }\end{array}$ & $\begin{array}{c}\% \text { of solubilized } \\
\text { proteins }^{* *}\end{array}$ \\
\hline CHAPS & 1 & 46.2 & 36.2 \\
CHAPSO & 1 & 40 & 31.4 \\
n-octyl-bD-glucoside & 0.75 & 31.2 & 30 \\
MEGA-8 & 1 & 17.5 & 76.9 \\
MEGA-9 & 0.75 & 24.2 & 30 \\
n-cotyl-b-D-thioglucoside & 1.5 & 42 & 19.6 \\
n-heptyl-b-D-thioglucoside & 1 & 13.3 & 25.4 \\
\hline * Percentage of specific binding activity of the solubilized proteins in the supernatants of that in \\
the crude membrane fractions. \\
** Percentage of extracted protein concentrations in the supernatants of that in the crude mem- \\
brane fractions.
\end{tabular}

CHAPSO, and OTG showed high percentages of specific binding, while CHAPS and CHAPSO solubilized moderate amounts of proteins (Table 1). Accordingly, we selected CHAPS for the initial solubilization of the ecdysone binding sites in membrane.

Solubilization of proteins in P1 and P2 membrane fractions When crude membranes were extracted with $1 \mathrm{M} \mathrm{NaCl}$, most ecdysone binding activity occurred in the precipitate (P1). Since $1 \mathrm{M} \mathrm{NaCl}$ is capable of separating peripheral proteins from the membrane, the P1 fraction may have consisted of integral membrane proteins, indicating that the ecdysone binding sites are associated with integral membrane proteins. After treatment of the P1 fraction with $0.05 \%$ MEGA-8, the major binding activity was detected in the precipitate (P2), showing that $0.05 \%$ MEGA-8 did not solubilize integral membrane proteins but merely fragmented membranes (Elmogy et al., 2004). Based on these preliminary results, we tried to find the optimal conditions for solubilization of the ecdysone binding sites using P2 pellets prepared according to our previous results (Elmogy et al., 2004). P1 pellets were resuspended in the assay buffer and treated with combinations of increasing CHAPS and $\mathrm{NaCl}$ concentrations for $60 \mathrm{~min}$ at $4^{\circ} \mathrm{C}$. After centrifugation of the suspension, the binding activities in the resulting supernatants were assayed (Fig. 2). Solubilization of PonA binding activity depended on the ionic strength of the solubilization buffer, with the maximum binding activity at $0.6 \%$ CHAPS containing $1 \mathrm{M} \mathrm{NaCl}$, and at $1.0 \%$ CHAPS containing 0.5 or $0.1 \mathrm{M}$ $\mathrm{NaCl}$. The binding activity in the solubilized fractions did not display a sigmoid curve, as a single peak is appeared, which may have been the result of progressive solubilization. The decrease may have been caused by inactivation at higher detergent concentrations (Fig. 2).

P2 was treated with increasing detergent concentrations at $1 \mathrm{M} \mathrm{NaCl}$, and ecdysone binding activity was measured (Fig. 3). Optimal solubilization was achieved at $0.6 \%$ CHAPS, yielding $75.1 \%$ binding activity relative to specific binding of the crude membrane fractions.

The concept of micelle formation is relevant to solubilization and reconstitution studies of membrane proteins, since it appears that there is some correlation between the ability to form micelles and the concentration of the detergent required for solubilization (Rivnay and Metzger, 1982). $\mathrm{CMC}$, critical miceller concentration, is an important param-

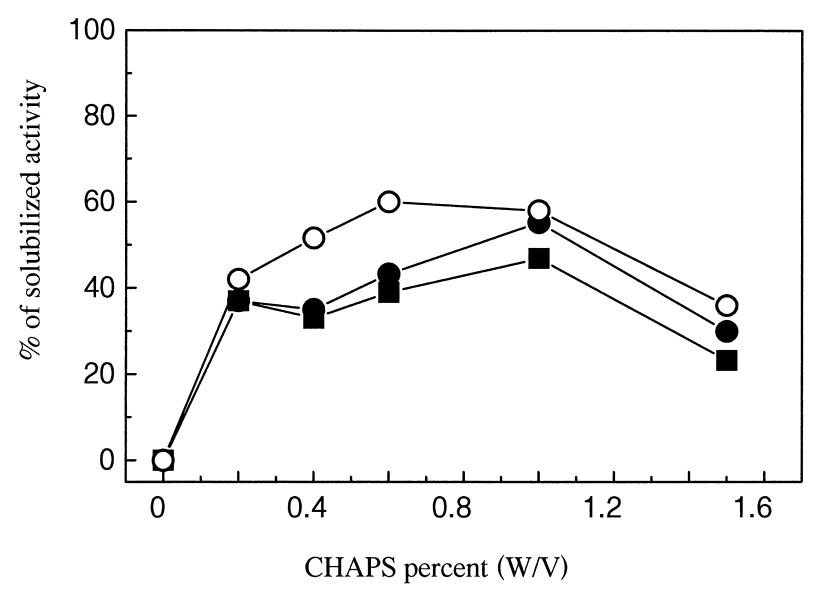

Fig. 2. Solubilization of $P 1$ membranes with different concentrations of CHAPS and $\mathrm{NaCl}$. P1 membranes of ASGs, prepared as described in materials and methods, were suspended in assay buffer to a final protein concentration of $1 \mathrm{mg} / \mathrm{ml}$ and treated with combinations of increasing concentrations of $\mathrm{CHAPS}$ and $\mathrm{NaCl}$ for $60 \mathrm{~min}$ at $4^{\circ} \mathrm{C}$. Binding activity in the dialyzed supernatants was assayed with $25 \mathrm{nM}$ of $\left[{ }^{3} \mathrm{H}\right] \mathrm{PonA}$ under standard assay conditions. These activities were regarded as solubilized activities. The ordinate is solubilized binding activity shown as the percentage of that in the crude membranes. Open squares, $100 \mathrm{mM} \mathrm{NaCl}$; closed circles, $500 \mathrm{mM} \mathrm{NaCl}$; open circles, $1 \mathrm{M} \mathrm{NaCl}$. Each datum point is the mean of duplicate determinations.

eter for a given detergent, since at this concentration, the detergent starts to accumulate in the membrane. It is known that the addition of salt dramatically decreases the CMC of charged detergents such as sodium dodecyl sulfate (SDS) (Reynolds and Tanford, 1970; Mukerjee et al., 1970; Chattopadhyay and London, 1984); ionic interactions are reduced with an increase in salt concentration, leading to more effective dissociation of the membrane protein from the non-soluble membrane constituents as well as from other soluble molecules. We found that CHAPS was ineffective in solubilizing ecdysone binding sites from membranes in the absence of $\mathrm{NaCl}$. Therefore, we performed analogous studies with P1 membranes (Fig. 2). The solubilization efficiency of CHAPS increased with increasing salt concentration. CHAPS in the presence of $\mathrm{NaCl}$ efficiently solubilizes G-protein-coupled serotonin $1 \mathrm{~A}$ receptors from bovine hippocampus and from Chinese hamster ovary cells 


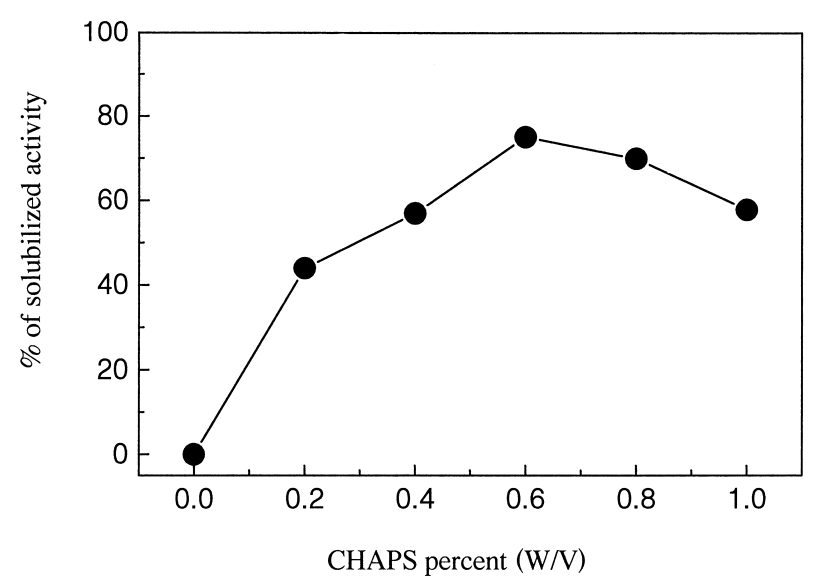

Fig. 3. Solubilization of $P 2$ membranes of ASGs using different concentrations of CHAPS and $1 \mathrm{M} \mathrm{NaCl}$. P2 membranes of ASGs, prepared as described in Materials and Methods, were suspended in assay buffer to a final protein concentration of $1 \mathrm{mg} / \mathrm{ml}$ and treated with combinations of increasing concentrations of CHAPS and $1 \mathrm{M}$ of $\mathrm{NaCl}$ for $60 \mathrm{~min}$ at $4^{\circ} \mathrm{C}$. Binding activity in the dialysed supernatants was assayed with $25 \mathrm{nM}$ of $\left[{ }^{3} \mathrm{H}\right] \mathrm{PonA}$ under standard assay conditions. These activities were regarded as solubilized activities. The ordinate is solubilized binding activity shown as the percentage of that in the crude membranes. Each datum point is the mean of duplicate determinations.

(Chattopadhyay and Harikumar, 1996; Chattopadhyay et al., 2002, 2004), nicotinic acetylcholine receptors (Schurholz, 1996), dopamine-D2 receptors from synaptosomal membranes of the bovine caudate nucleus (Kidric et al., 1984), and the binding sites for gonadotropin-releasing hormone from pituitary plasma membranes (Winiger et al., 1983).

\section{Dissociation of the solubilized mixed micelles}

Solubilization of membrane proteins is a process in which the proteins and lipids that are held together in the native membrane are suitably dissociated in a buffered detergent solution. The controlled dissociation of the membrane results in the formation of small protein and lipid clusters that remain dissolved in the aqueous solution. Solubilization therefore involves multiple changes in the organization of membranes and depends on a variety of membrane parameters. Accordingly, we next tried to establish experimental conditions to dissociate the protein/lipid/ CHAPS mixed micelles we obtained into protein/detergent and lipid/detergent complexes that retained binding activity, so as to decrease the size of the micelles for $\mathrm{mEcR}$ protein purification. Different amounts of MEGA-8, CHAPS, and CHAPSO were added to aliquots of the dialyzed protein/ lipid/CHAPS mixed micelles to yield detergent/protein ratios of 1:1 and 15:1 (Fig. 4). The binding activity decreased to approximately $40 \%$ and $15 \%$ at the ratio of $1: 1$ for CHAPS and MEGA-8, respectively. Binding activity decreased with increasing CHAPSO concentrations from $70 \%$ of the original binding activity at the detergent/protein ratio of $1: 1$ to $8 \%$ at the ratio of $15: 1$. It has been established that an increase in the detergent ratio results in more delipidation of mixed micelles, and that lipid-free protein/detergent complexes are formed at detergent:protein ratios of 10:1 to 20:1 (Hjelmeland and Chrambach, 1984). Accordingly, the

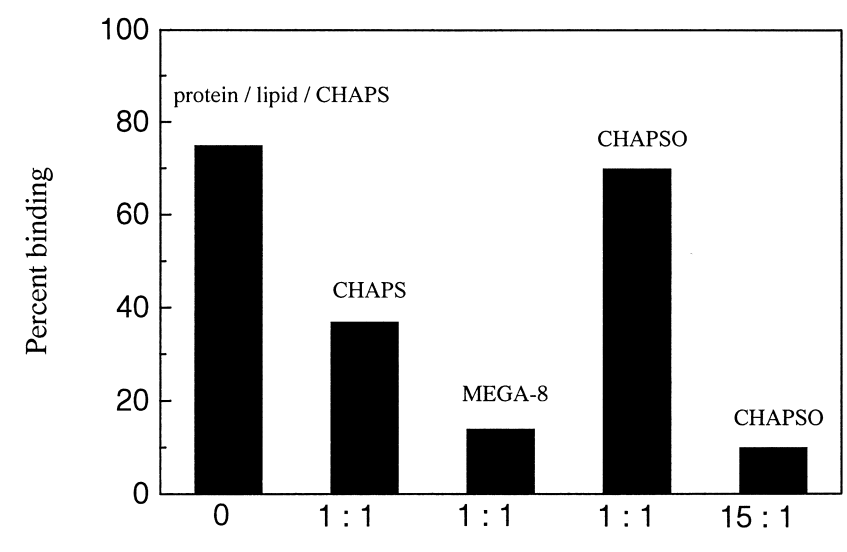

Ratio of detergent to solubilized protein

Fig. 4. Dissociation of the mixed micelle complex. To aliquots of dialyzed protein/ lipid/CHAPS mixed micelles $(100 \mu \mathrm{g})$, CHAPS, MEGA-8, or CHAPSO was added to yield a detergent/protein ratio of $1: 1$ for the detergents CHAPS, and MEGA-8; $1: 1$ and $15: 1$ for CHAPSO. After incubation for $60 \mathrm{~min}$ at $4^{\circ} \mathrm{C}$, binding activity was measured and is expressed as a percentage of the binding measured in the crude membranes.

observed decrease in binding activity after treatment with MEGA-8 at a 1:1 ratio, CHAPS at a 1:1 ratio, and CHAPSO at a $15: 1$ ratio (Fig. 4) may have been due to conformational changes in the macromolecule upon substitution of the detergents for the lipid in the microenvironment of the receptor protein.

In conclusion, we defined experimental conditions that allowed solubilization from ASGs membranes of putative membrane ecdysone receptor that retained $75 \%$ of its native binding activity, thereby yielding protein/detergent complexes with partial binding activity. This makes it possible to purify membrane-bound ecdysone binding protein.

\section{ACKNOWLEDGMENTS}

This work was supported by a Grant-in-Aid for Scientific Research from the Japan Society for the Promotion of Science (No. 14360033) to S.S.

\section{REFERENCES}

Banerjee P (1999) Detergents. In "Encyclopedia of Molecular Biology" Ed by E Creighton, Wiley, New York, pp 661-666

Banerjee P, Joo JB, Buse JT,Dawson G (1995) Differential solubilization of lipids among with membrane proteins by different classes of detergents. Chem Phys Lipids 77: 65-78

Beato M, Klug J (2000) Steroid hormone receptors: an update. Hum Reprod Update 6: 255-236

Chattopadhyay A, Harikumar KG (1996) Dependence of critical micelle concentration of a zwitterionic detergent on ionic strength: implications in receptor solubilization. FEPS Lett 391: 199-202

Chattopadhyay A, London E (1984) Fluorimetric determination of critical micelle concentration avoiding interference from detergent charge. Anal Biochem 139: 408-412

Chattopadhyay A, Harikumar KG, Kalipatnapu S (2002) Solubilization of high affinity $\mathrm{G}$-protein-coupled serotonin $1 \mathrm{~A}$ receptors from bovine hippocampus using pre-miceller CHAPS at low concentration. Mol Memb Biol 19: 211-220

Chattopadhyay A, Jafurulla M, Kalipatnapu S (2004) Solubilization of serotonin1 A receptors heterologously expressed in Chinese hamster ovary cells. Cell Mol Neurobiol 24: 293-300 
Elmogy M, Iwami M, Sakurai S (2004) Presence of membrane ecdysone receptor in the anterior silk gland of the silkworm, Bombyx mori. Eur J Biochem 271: 3171-3179

Elmogy M, Terashima J, Iga, M, Iwami M, Sakurai S (2006) A rapid increase in cAMP in response to 20hydroxyecdysone in the anterior silk glands of the silkworm, Bombyx mori. Zool Sci 23: 715-719

Falkenstein E, Tillmann H, Christ M, Feuring M, Wehling M (2000) Multiple actions of steroid hormones - a focus on rapid, nongenomic effects. Pharmacol Rev 52: 513-555

Garavito RM, Ferguson-Miller S (2001) Detergents as tools in membrane biochemistry. J Bio Chem 276: 32403-32406

Hjelmeland LM (1980) A nondenaturing zwitterionic detergent for membrane biochemistry: design and synthesis. Proc Natl Acad Sci U.S.A 77: 6368-6370

Hjelmeland LM, Chrambach A (1984) Solubilization of functional membrane proteins. Method Enzymol 104: 305-318

Henrich VC, Rybczynski R, Gilbert LI (1999) Peptide hormones, steroid hormones, and puffs: mechanisms and models in insect development. Vitam Horm 55: 73-125

Jones OT, Earnest JP, McNamee MG (1987) Solubilization and reconstitution of membrane proteins. In "Biological Membranes: A Practical Approach" Ed by JBC Findlay, WH Evans, IRL Press, Oxford, pp 139-177

Kerkhoof C, Gehring L, Habben K, Resch K, Laever V (1996) Identification of two different lysophosphatidyl choline: acyl-CoA acyltransferase (LAT) in pig spleen with putative distinct topological localization. Biochem Biophys Acta 1302: 249-256

Kerkhoof C, Trumbach B, Gehring L, Habben K, Schmitz G, Kaever V (2000) Solubilization, partial purification and photolabelling of the integral membrane protein lysophospholipic: acylCoAacyltransferase (LAT). Eur J Biochem 267: 6339-6345

Kidric M, Petrovic J, Soskic V, Trajkovic D (1984) Solubilization of dopamine D2 receptor from synaptosomal membranes of the bovine caudate nucleus. Br J Pharmacol 83: 687-695

Mukerjee P, Perrin J, Witzke E (1970) Effect of micelle formation on optica rotatory dispersion of beta-D-octyl glucoside. J Pharm Sci 59: 1513-1515

Neugebauer JM (1990) Detergents: an overview. Methods Enzymol 182: $239-253$
Ofri D, Ritter AM, Lui Y, Gioannini TL, Hiller JM, Simon EJ (1992) Characterization of the solubilized opioid receptors: reconistitution and uncoupling of guanine nucleotide-sensitive agonist binding. J Neurochem 58: 628-635

Reynolds JA, Tanford C (1970) Binding of dodecyl sulfate to proteins at high binding ratios: possible implications for the state of proteins in biological membranes. Proc Natl Acad Sci USA 66: 1002-1007

Rivnay B, Metzger H (1982) Reconstitution of the receptor for immunoglobulin $\mathrm{E}$ into liposomes: conditions for incorporation of the receptor into vesicles. J Biol Chem 257: 12800-12808

Riddiford LM, Cherbas P, Truman JW (2000) Ecdysone receptors and their biological actions. Vitam Horm 60: 1-73

Sarramegna V, Muller I, Talmont F (2006) Recombinant G proteincoupled receptors from expression to renaturation: a challenge towards structure. Cell Mol Life Sci 63: 1149-1164

Schurholz T (1996) Critical dependence of the solubilization of lipid vesicles by the detergent CHAPS on lipid composition: functional reconstitution of the nicotini acetycholine receptor into preformed vesicles above the critical micellization concentration. Biophys Chem 58: 87-96

Tanford C, Reynolds JA (1976) Characterization of membrane proteins in detergent solutions. Biochem Biophys Acta 457: 133170

Terashima J, Yasuhara N, Iwami M, Sakurai S (2000) Programmed cell death triggered by insect steroid hormone, 20hydroxyecdysone, in the anterior silk gland of the silkworm, Bombyx mori. Dev Genes Evol 210: 545-558

Watson CS, Gametchu B (1999) Membrane initiated steroid actions and the proteins that mediate them. PSEBM 220: 9-19

Winiger BP, Birabeau MA, Lang U, Capponi AM, Sizonenko PC Aubert ML (1983) Solubilization of pituitary GnRH binding sites by means of a zwitterionic detergent. Mol Cell Endocrinol 31: 77-91

Yoshikuni M, Shibata N, Nagahama $Y$ (1993) Specific binding of $\left[{ }^{3} \mathrm{H}\right]$ 17a, 20b dihydroxy-4-pregnen-3-one to oocyte cortices of rainbow trout (Oncorhynchus mykiss). Fish Physiol Biochem 11: 15-24

(Received March 30, 2007 / Accepted May 20, 2007) 